\title{
INVESTIGATION OF SOME ENZYMES LEVEL IN BLOOD AND MILK SERUM IN TWO STAGES OF MILK YIELD DAIRY COWS AT ASSIUT CITY
}

\author{
GHADA A.E. MOHAMED
}

Animal Health Research Institute, Assiut, Egypt.

Email: dr_kada2012@yahoo.com

\section{ABCTRACT}

Received at: 17/6/2014

Lactation has a great impact on biochemical parameters in the blood of cows, reflecting on metabolic demands. A part of that test is determining enzyme

Accepted: 6/8/2014 activities in the serum. This study was conducted on 40 head of Friesian dairy cows apparently healthy, were divided into two groups the first is the early lactation (15 days to 2 months), and the second group is mid lactation (75 days to 4 months) collected blood samples and draw blood serum purified to measure some routine biochemical changes as total protein, albumin, globulin mathematically and total bilirubin are generally used for the evaluation of metabolic status and activity of enzymes Aspartate aminotransferase (AST), Alanine aminotransferase (ALT), Gamma-glutamyl-transferase (GGT), and Alkaline phosphatase (ALP). Milk samples were taken from cows under study to measure the activity of enzymes (AST, ALT, ALP, GGT), The study showed the presence of significant differences in both total protein, globulin mathematically, total bilirubin in two group, and a significant difference in the activity of AST, ALP in the blood serum in two stages and no significant difference in the activity of enzymes in the whey in two stage with the existence of marked increase activity of (ALT, ALP, GGT), and decrease activity of AST in milk than blood serum. The results indicated that AST activity appeared significantly lower in milk than that in blood $(p=0.0002)$ and $=0.0035)$ in two stage of lactation respectively, also ALT, ALP, GGT was highly significant in milk than blood serum $(P=0.0290,<0.0001,<0.0001)$ in early lactation, and $(p$ $=0.0102,<0.0001,<0.0001)$ in mid lactation.

Key words: Lactating cow-milk- enzyme activities-blood serum

\section{INTRODUCTION}

Multiparous dairy cow puts the production capabilities of cows at risk, which can result in metabolic disorders, In order to predict such disorders and eventual sub clinical diseases it is necessary to determine physiological ranges of biochemical parameters in a clinically healthy herd (Mulligan et al., 2006).

Dairy cows are more susceptible to various diseases in the postpartum period when compared to other production periods, due to the negative energy balance, weakened appetite and increasing yield. That is a period particularly favourable for metabolic disorders (Mordak and Nicpoń., 2006).

Alanine aminotransferase (ALT), Aspartate aminotransferase (AST), $\gamma$-glutamyltransferase (GGT), and alkaline phosphatase (ALP) are important catabolic enzymes, which play an important role in liver function of animals. Blood plasma and serum ALT, AST, ALP and GGT activities were reported to be useful for postpartum Holstein cows (Stojević et al., 2005; and Śamanc et al., 2011).

While little information is available concerning about the activity changes of ALT, AST, GGT and ALP in milk. The activities of these enzymes were monitored in milk and blood serum of cows (Liu et al., 2012 and 2013). A majority of enzymes which were exist in the breast cells derived from some enzyme of blood and measurement of the activity of such enzymes in milk has been used to monitor udder health in dairy cows (Fox and Kelly, 2006). More practical attention has been given to detection of enzyme activity in milk, and many enzymes have been proposed and listed as reliable markers for early diagnosis of subclinical disease (Babaei et al., 2007; Katsoulos et al., 2010).

AST activity has been extensively studied in both animals and humans. For instance, it was found that 
the variation of AST had some relations with the function of liver, skeletal muscle and heart of cows (Kaneko et al., 2008). In addition, AST is proposed to be one of the common parameters for the detection and diagnosis of liver failure (Sattler and Fürll, 2004). The activity of blood aminotransferases is very important because they act as a catalyst in connection to the metabolism of amino acids and carbohydrates. Changes in their activity in the blood can be a consequence of their increased activity in cells, or damages in cell structure (Milinković-Tur et al., 2005). The high concentrations of GGT in blood are detected in the liver, kidney, pancreas, spleen, intestine, heart, and the brain of mammalian tissue (Tennant, 1997). And the GGT activity is relatively high in liver of cow (Milinković-Tur et al., 2005).

ALP, which is a membrane-bound glycoprotein mainly found in animal tissues such as liver, bone, with a lesser amounts in kidney, intestine and placenta (Ali et al., 2005 and Webber et al., 2010), is used as a biochemical marker to diagnose osteoporosis and hepatobiliary disorders as well as fatty liver disease (Webber et al., 2010; Hanley et al., 2005).

ALT is one of the important enzymes for protein catabolism. Its main function is to catalysis alanine and alpha ketoglutarate and transfer them into generates pyruvate and glutamate. It plays an important role in the process of glucose and amino acid of intermediate metabolism. (Ray et al., 2008).

Normally, only a little ALT release into the blood, lead to increase significantly the plasma ALT activity while the cytosol of ALT leak into the blood at the condition of a liver cell injury such as all kinds of hepatitis, drug toxicity liver cell necrosis and other diseases (Anderson et al., 2000; Puoti et al.; 2005 and Lai et al., 2007). Therefore, it is one of the important indexes of clinical diagnosis of liver function (Kaplwitz, 2000). Because of dairy cows especially with a high production thus in the early lactation cows with high body fat mobilization were formed which can easily lead to liver function injury (Stojevic et al., 2005). During the period of the postpartum, negative energy balance was caused by the body's physical consumption which was the result of the mobilization of body fat and liver injury and the variation of liver cell permeability which lead to variable degree of increase enzymes (Bjerre-Harpøth et al., 2012).

The aim of this study was to estimate enzyme levels in blood and milk serum, in multiparous cows during early and mid lactation period, and to identify changes that occur as a consequence of physiological processes and changes in the metabolic status in good time.

\section{MATERIALS and METHODS}

\begin{abstract}
Animals
A total number of 40 multiparous dairy cow were divided into two groups according to the day of lactation (15day-2month) $n=20$ and the other (75day4 month) $n=20$. These were apparently healthy free of clinical mastitis and any other udder lesions, were examined and selected from a privet farm at Assiut city.
\end{abstract}

\section{Samples}

Blood serum samples (without anticoagulant) were collected through jugular vein puncture, centrifugation at $1,800 \times \mathrm{g}$ for $15 \mathrm{~min}$ to obtain clear non haemolysed sera and kept in clean dry tubes (Eppendrof tubes), stored at $20^{\circ} \mathrm{C}$ until testing.

Milk samples were collected in the morning, defatted by centrifugation at $3000 \times \mathrm{g}$ for $10 \mathrm{~min}$ at $4^{\circ} \mathrm{C}$ in hypothermal ultracentrifuge to obtain pellucid milk serum. Withdrawn the whey in clean dry tubes (Eppendrof tubes), stored at $20^{\circ} \mathrm{C}$ until testing.

\section{Biochemical analysis}

Blood serum sample were used for determination of total protein, albumin concentration and total bilirbin determinations by using standard test kits supplied by Spectrum Diagnostic, Company (Egypt) with Semiautomatic biochemical Analyzer. Globulin concentration mathematically was calculated as the difference between total protein and albumin. Calculate the $\mathrm{A} / \mathrm{G}$ ratio. Blood serum and defatted milk used for enzyme estimations alanine aminotransferases (ALT, EC 2.6.1.2), aspartate aminotransferase (AST, EC 2.6.1.1), $\gamma$ glutamyltransferase (GGT EC2.3.2.2) and alkaline phosphatase (ALP EC 3.1.3.1). Enzymes activities were estimated using commercial kinetic assay test kits Spectrum Diagnostic Company (Egypt). The standardized protocol provided with the kit was followed for estimation. The final results were reported in units per L of (blood, milk) serum (U/L). Serum activities were determined using a biochemical automatic analyzera.

Statistical analysis: The data was analyzed with the statistical package (SPSS 2000). In order to detect statistically significant differences, the data was summarized with descriptive statistics: mean $(\mathrm{M}) \pm$ standard error ( \pm SEM). Student's unpaired $t$-test was used to evaluate data of enzyme activity in blood and milk serum. Comparisons between two groups were determined significant at $\mathrm{p}<0.05$ level. 


\section{RESULTS}

The recorded mean values of some blood serum biochemical levels in the two groups of dairy cow are recorded in Table 1 . The effect of stage of lactation on total protein, albumin globulin, $\mathrm{A} / \mathrm{G}$ ratio and total bilirbine levels showed that total protein and globulin statistically significant higher in early lactation cows $p=(0.0041,0.0062)$ and total biliribin $p=(0.0231)$. Enzyme activities in blood serum of two outcome groups are presented in Table 2 The mean values AST and ALP were statistically significant different at $(P<0.05)$. AST highly significant in early lactating cows $(p<0.0001)$, while ALP highly significant in mid lactation cows $(\mathrm{p}=0.0062)$, and no significant different of ALT and GGT mean values $(P>0.05)$ in tow group. Enzyme activities in milk serum of two outcome groups are presented in Table 3 showed no significant different of AST, ALT, ALP, GGT mean values in tow group of lactating cows $(P>0.05)$. Comparison between the estimated blood and milk serum enzyme activities in early and mid lactating cows are presented in Tables 4,5. The AST activity in milk was much lower than that in blood serum $(P<0.05)$. Compared to other three enzymes, which are ALT is slightly higher, and ALP, GGT much higher in milk than blood serum.

Table 1: Mean values (Mean \pm SEM) of some serum biochemical parameters in two group of lactating cows.

\begin{tabular}{lccc}
\hline \multicolumn{1}{c}{ Parameter } & $\begin{array}{c}\text { Early lactating cows } \\
\mathbf{N}=\mathbf{2 0}\end{array}$ & $\begin{array}{c}\text { Mid lactating cows } \\
\mathbf{N = 2 0}\end{array}$ & $\boldsymbol{p}$ value \\
\hline Total protein $(\mathrm{g} / \mathrm{dl})$ & $9.39 \pm 0.365^{* *}$ & $8.04 \pm 0.249$ & 0.0041 \\
\hline Albumin $(\mathrm{g} / \mathrm{dl})$ & $3.07 \pm 0.067 \mathrm{~ns}$ & $3.056 \pm 0.099$ & 0.9081 \\
\hline Globulin $(\mathrm{g} / \mathrm{dl})$ & $6.323 \pm 0.368^{* *}$ & $4.985 \pm 0.277$ & 0.0062 \\
\hline A/G ratio & $0.5226 \pm 0.037 \mathrm{~ns}$ & $0.684 \pm 0.074$ & 0.0604 \\
\hline Total bilirubin $(\mu \mathrm{mol} / \mathrm{L})$ & $6.818 \pm 0.415^{*}$ & $5.370 \pm 0.409$ & 0.0231 \\
\hline
\end{tabular}

Table 2: Mean values (Mean $\pm \mathrm{SEM})$ of blood serum enzyme activities (U/L) in two group of lactating cows.

\begin{tabular}{cccc}
\hline Parameter & Early & Mid & $\boldsymbol{p}$ value \\
\hline AST & $98.35 \pm 5.504^{* * *}$ & $68.05 \pm 3.197$ & $<0.0001$ \\
\hline ALT & $44.05 \pm 3.418$ & $40.70 \pm 2.157$ & $0.4124 \mathrm{~ns}$ \\
\hline ALP & $90.90 \pm 5.977$ & $134.4 \pm 13.77^{* *}$ & 0.0062 \\
\hline GGT & $57.85 \pm 6.450$ & $46.60 \pm 5.117$ & $0.1798 \mathrm{~ns}$ \\
\hline
\end{tabular}

Table 3: Mean values (Mean \pm SEM) of milk serum enzyme activities (U/L) in two group of lactating cows.

\begin{tabular}{cccc}
\hline Parameter & Early & Mid & $\boldsymbol{p}$ value \\
\hline AST & $51.30 \pm 9.954$ & $48.45 \pm 5.424$ & $0.8028 \mathrm{~ns}$ \\
\hline ALT & $79.45 \pm 15.22$ & $69.15 \pm 10.30$ & $0.5784 \mathrm{~ns}$ \\
\hline ALP & $1771 \pm 330.0$ & $2253 \pm 288.7$ & $0.2786 \mathrm{~ns}$ \\
\hline GGT & $3152 \pm 322.1$ & $2565 \pm 414.3$ & $0.2704 \mathrm{~ns}$ \\
\hline
\end{tabular}

Table 4: Comparison between the estimated blood and milk serum enzyme activities (U/L) in early lactating cows.

\begin{tabular}{cccc}
\hline Parameter & $\begin{array}{c}\text { Enzyme in serum } \\
(\text { Mean } \pm \text { SEM) }\end{array}$ & $\begin{array}{c}\text { Enzyme in milk } \\
(\text { Mean } \pm \text { SEM) }\end{array}$ & $p$ value \\
\hline AST & $98.35 \pm 5.504 * * *$ & $51.30 \pm 9.954$ & 0.0002 \\
\hline ALT & $44.05 \pm 3.418$ & $79.45 \pm 15.22 *$ & 0.0290 \\
\hline ALP & $90.90 \pm 5.977$ & $1771 \pm 330.0 * * *$ & $<0.0001$ \\
\hline GGT & $57.85 \pm 6.450$ & $3152 \pm 322.1 * * *$ & $<0.0001$ \\
\hline
\end{tabular}


Table 5: Comparison between the estimated blood and milk serum enzyme activities (U/L) in mid lactating cows.

\begin{tabular}{cccc}
\hline Parameter & $\begin{array}{c}\text { Enzyme in serum } \\
\text { (Mean } \pm \text { SEM) }\end{array}$ & $\begin{array}{c}\text { Enzyme in milk } \\
(\text { Mean } \pm \text { SEM) }\end{array}$ & $p$ value \\
\hline AST & $68.05 \pm 3.197 * *$ & $48.45 \pm 5.424$ & 0.0035 \\
\hline ALT & $40.70 \pm 2.157$ & $69.15 \pm 10.30 *$ & 0.0102 \\
\hline ALP & $134.4 \pm 13.77$ & $2253 \pm 288.7^{* * *}$ & $<0.0001$ \\
\hline GGT & $46.60 \pm 5.117$ & $2565 \pm 414.3^{* * *}$ & $<0.0001$ \\
\hline
\end{tabular}

NB: Results are expressed as Means \pm Standard errors (SEM).

For all tests, values of $P<0.05$ were considered significant.

\section{DISCUSSION}

Dairy cows under stressful during the different stage of lactation especially early, due to energy expenditure associated with milk production and limited feed intake (Rajala- Schultz et al., 1999). And this negative energy balance (NEB) or imbalance increases fat mobilization, and high mobilization of lipids

From body fat reserve, can be a result of cell structure damage or changes in enzyme activity such as AST, ALT, GGT and ALP in the liver. (Rukkwamsuk et al., 2000).

In the present study the mean values of total protein and globulin is significantly higher in early lactating cows than mid lactating $(\mathrm{p}=0.0041,=0.0062)$. The total protein concentration significantly varied during the two milking period and variations was caused by highest globulin levels seen in the lactating cows in early lactating cow. In contrast, albumin levels were constant during the two stag. Nevertheless, the values in mid lactation were within the published reference ranges (Kaneko et al., 1997). and the normal concentration values of total proteins and globulins in the dairy cows range respectively from 6,7 to $8,7 \mathrm{~g} / \mathrm{dl}$ and 3,0 to $5,4 \mathrm{~g} / \mathrm{dl}$ (Brent and Todd 2003; Herdt, 2000). In early lactating cows globulin were the highest which resulted albumin-toglobulin ratio was the lowest as shown in (Table1). The physiological status of the cows significantly affected the serum levels of some blood constituents. All these differences could be related to the differences in the animal's metabolism, needs for milk production and metabolic changes. Piccione et al. (2012) observed that the total serum proteins levels were significantly affected from the physiological period and increased during Lactation. The variations reflect the maternal requirements of proteins need for milking and providing Immunoglobulin (Bell et al., 2000; Mohri et al., 2007). The higher concentrate-to-forage ratio provided during the lactation is generally associated with lower levels of fiber and higher levels of starch in the diet, which gives rise to an increased production of propionic acid in the rumen and an increased microbial protein supply (Heck et al., 2009). This is reflected, in our study, by an increase of total serum protein during the early lactation, and a slight decrease during the mid period.

The mean value of total bilirubin was slightly higher in early lactating cows ( $p=0.0231)$. The results of the present study demonstrate a lower risk of hyperbilirubinemia incidence in cows when compared with these in mid lactation. The value of that index in cows with subclinical ketosis was at the level of $7.27 \mu \mathrm{mol} / 1$ (Nowakowski, 2008). Marczuk $\&$ Filar (2003) point out the special usefulness of the determination of GGT, AST activity and bilirubin concentration for the recognition of subclinical impairments and liver disorders like fatty liver liver in 1-2 weeks postpartum which was $14.2 \mu \mathrm{mol} / 1$.

The concentration of total bilirubin during the two research period was not intensified and did not exceed the reference values (Meyer and Harvey 1998). Intensive postpartal lipid mobilization and ketogenesis are sufficient for a series of compensatory metabolic processes with changes in blood metabolic profile during early-lactation in healthy cows (Cincović et al., 2012). Furthermore, the excretory function of hepatocytes is reduced and, accordingly, the blood concentrations of some compounds such as total bilirubin is generally increased (West, 1990; Veenhuizen et al., 1991; Sevinc et al., 2003 and Bobe et al., 2004).

Enzymes activities in blood serum: Estimation of enzymes showed that AST activity was significantly higher in early lactation cows $(p<0.0001)$ (Table 2$)$. The increase in AST concentration after parturition could be explained by the degradation of muscle cells caused by mobilization of body reserves (Sattler and Furll, 2004). Moreover, increased AST values may be due to protein mobilization from muscles for gluconeogenesis (Cardoso et al., 2008). And that lactation has a great impact on the intensity of metabolism and on metabolic parameters in the blood and this agree with the result of Filipejová and Kováčik. (2009) who found that the concentration of 
AST $(1.42 \pm 0.31 \mu$ kat.1-1) in dairy cows at the beginning of lactation was significantly higher $(p<0.01)$ in comparison with the dry period (0.88 $\pm 0.31 \mu$ kat.1-1).

Same result was observed by Djoković et al. (2013) who found that AST concentration $69.46 \pm 27.54 \mathrm{IU} / 1$ in early-lactation cows which is higher than $39.31 \pm 18.90 \mathrm{IU} / 1$ in mid lactation, Add that metabolic changes during early lactation were more intensive as a function of (EB) enrage balance, compared to mid lactation These changes are due to both lipolysis and ketogenesis occurring during homeorhetic processes and metabolic adaptation in the liver during early lactation.

Kaneko et al. (1997) mentioned that the value of AST activity in cows was $105 \pm 27 \mathrm{U} / \mathrm{L}$, while the value in the study by Stojević et al. (2005) was at 10-45days of lactation, $57.79 \pm 16.49 \mathrm{u} / 1$ and at 4690 days of lactation, $45.82 \pm 7.39 \mathrm{u} / 1$ and at 91 day until the end of lactation, $44.91 \pm 6.93$ with a mean value in all cows $43.35 \pm 13.56 \mathrm{U} / \mathrm{L}$ which is lower than recorded in Kauppinen's study (1984) values were shown for a group of healthy cows from 65.05 $\pm 31.31 \mathrm{U} / \mathrm{L}$. The higher value in our study reflect that cow under post partial physiological stress.

No significant difference observed in ALT activity in blood serum of two stage of lactating cows (Table 2). Despite of higher mean value in The two stages the same result shown by Joźwik et al. (2012) who observed a high level of AST, ALT, GGT (58-100, 25-74, and 22-64) units/1, respectively and they add that the obtained results show the influence of milk yield and stage of lactation on the activity of liver enzymes, When there is damage to the liver cells, the aminotransferase enzym level increases in the blood. On the other hand, ALT was maintained at significantly greater concentrations throughout two stage, suggesting that the liver is still in a state of hyperfunction coinciding with mammary gland activity (Sarma and Ray, 1985). Determination of Alanine aminotransferase (ALT) activity plays an important role in the diagnosis of cows manifest hypernomic fat mobilization in early lactation which causes liver function injury and lead to variation of activity (Kramer and Hoffman, 1997). Stojević et al. (2005) recordede low level of ALT activities was in the range of 5.24-29.68 U/L, and mean value was $14.89 \pm 5.88 \mathrm{U} / \mathrm{L}$ than values of (Kaneko et al., 1997) which was $27 \pm 14 \mathrm{U} / \mathrm{L}$, and activities recorded by same auther lower with compared to Kauppinen's (1984) values of $17.82 \pm 11.51 \mathrm{U} / \mathrm{L}$. The author considers that the role of ALT in predicting liver damage in ketosis is not significant. While ALT the normal range obtained by Brent and Todd. (2003) fell within (0 to $30 \mathrm{U} / \mathrm{L}$ ).
Table 2 shows that ALP activity in blood serum is highly significant $(p=0.0062)$ with mean value of $134.4 \pm 13.77 \mathrm{u} / \mathrm{l}$, and $90.90 \pm 5.977 \mathrm{u} / 1$ in $\mathrm{mid}$ and early lactating cow respectively. Alkaline phosphatase (ALP) in serum has been shown to consist of isoenzymes originating from the liver and bone, which have a long half-life, and these isoenzymes are mainly utilized as indices of liver function or bone metabolism in cattle.

Serum ALP activity increases in cases of hepatitis, biliary disorders, or during growth due to active bone metabolism (Carlson, 1996). The same result obtained by Sato et al. (2005) noted that serum ALP activity was found to be higher in lactational periods in comparison with the dry period, and it was clear that the increase in the serum activity was attributed to increases of bone ALP and liver ALP in the former period. Judging from the variation of liver ALP and AST, it appeared that liver function in the lactational period was not the same as in the dry period. A previous report has shown that bone metabolism is more active in lactational periods than in the dry period (Sato et al., a,b 2002). The reference range of serum ALP activity in cattle is very broad range and has been shown to be $0-488$ $\mathrm{U} / \mathrm{l}$. This value was determined without regard to lactation Kaneko et al. (1989) add that the broad range of reference values for cattle is due to the high level of serum ALP activity in lactating cows. In the present study the high significant increase of ALP in cows from day 75to 4 month my attributed to that cow in the peak of lactation.

The finding of present study showed no significant variation in levels of GGT activity in both group (Table 2) however it is slightly higher mean value in early than mid lactation $(57.85 \pm 6.450 \mathrm{u} / 1,46.60 \pm$ $5.117 \mathrm{u} / 1) p=0.1798$ the result agreement with the finding of Abdel-Raheem et al. (2010) find that serum GGT was higher during the whole lactation period in comparison dry dairy cow the same observed by El-sherif and Assad (2001) in sheep who stated that AST and GGT were high in post partum and positively correlated with milk yield conceding the mammary gland activity. Values obtained by Kaneko et al. (1997) $15.7 \pm 4.0 \mathrm{U} / \mathrm{L}$, and the activity by Kauppinen (1984) presented a value of $15.78 \pm 6.18 \mathrm{U} / \mathrm{L}$, which are less than in our study. Influence on tested values described changes are a reflection of metabolic events. We can assume that the statistically significant difference of enzyme activity in blood per certain production phase arises from the increased or decreased activity of these enzymes in cells, an average of GGT observed by Brent and Todd.

(2003) fell Between 3.6 to $39 \mathrm{U} / \mathrm{L}$ the highly mean value in this study may due to postpartum physiological stress. 
Enzymes activities in milk serum: Estimation of enzymes showed that no significant difference in AST, ALT, ALP, GGT in both lactation stage (Table 3 ). And it is clear that there is no influence of the stages of lactation on the presence of the enzyme in milk.

In the present study the mean value of AST activity in milk was $51.30 \pm 9.954$ and $48.45 \pm 5.424 \mathrm{U} / \mathrm{L}$ in early and mid lactating cow, which it is significantly lower than in blood serum in tow group ( $p=0.0002,0.0035)$ respectively (Tables 4,5$)$ which come in agreement with that reported by Liu et al. (2012) who recorded mean value of $\mathrm{AST}(\mathrm{U} / \mathrm{L})$ $27.20 \pm 0.90$ add that the AST activity in milk was much lower than that in blood plasma $(P<0.001)$. On the contrary to Batavani et al. (2003) observed that the level of AST activity in milk was higher than the level found in blood serum and proposed that a major source of AST in normal and mastitic milk was mammary gland secretory cells. Add that blood serum was not the sole source of these enzymes in ovine mastitic milk, and that it was probably liberated from udder parenchymal cells and from disintegrated leukocytes (Michel, 1979; Kitchen, 1981; Deianov, 1983; Kato et al., 1989).

In contrast Bogin and Ziv (1973) suggested that AST in bovine milk was essentially a blood serumderived enzyme but (Bogin et al., 1977). Found that Changes in enzyme activities in blood or other biological fluids such as milk can be a consequence of cell structural damage.

Calamari et al. (2005) concluded that the milk enzyme systems change throughout seasons, particularly during summer, these variations also affected by differences in milk yield and mammary gland health.

In the present study the mean value of ALT in milk $79.45 \pm 15.22 \mathrm{u} / \mathrm{I}$ and $69.15 \pm 10.30 \mathrm{u} / 1$ in early and $\mathrm{mid}$ lactating cow, which it is slightly significant higher than in blood serum in two group ( $p=0.0290,0.0102)$ respectively (Tables 4,5$)$. In contrast with Liu et al. (2012) recorded low mean value of $\operatorname{ALT}(\mathrm{U} / \mathrm{L})$ $13.61 \pm 0.49$ in milk, also add that the activities of ALT $(P<0.05)$ in milk appeared significantly lower in compared to the blood plasma, and activity of ALT in blood plasma and milk were the lowest comber to three other enzyme. But, the researches of the dynamic ALT activity changes in cows in the postpartum period are few or less in milk. Liu et al. (2013) detected ALT activity in both blood plasma and milk significantly increased and reached the peak at the same time at week 8 postpartum, these come agreement with our study that mean value high in early than mid lactation for both blood and milk serum.
Tables 4,5 show a higher significant mean value of ALP enzyme activity in milk than in blood serum $(1771 \pm 330.0 \mathrm{u} / 1,2253 \pm 288.70 \mathrm{u} / \mathrm{l})$ in the two stages of lactation. Furthermore, the activity of ALP in milk was almost as much fold as that in blood serum $(P<0.0001)$. Same result was obtained by Liu et al. (2012) recorded in cows 3-9 weeks postpartum, the mean value of ALP (U/L) 251.43 \pm 20.25 in milk contrast blood plasma $79.23 \pm 1.95$ surprisingly enzyme activities ALP in milk were significantly higher than that in blood plasma $(p<0.001)$ and it was activity in milk was nearly three fold as much as that in blood plasma, the activity of the enzymes originating from the blood increase and leak from the blood into the milk due to an increased permeability (Pyorala, 2003 and Batavani et al., 2003). Another researcher but many causes of presents of ALP in milk.

Katsoulos et al. (2010) reported that the origin of elevated ALP activity was from leukocyte and mammary epithelial and interstitial cells damaged during inflammation, particularly from disintegrated leukocytes. Which may occur by physical and mechanical irritation by lactation, but Zeinhom et al. (2013) observed high level ALP enzyme activity in mastatic milk as well as non specific mastitis showed high milk enzymatic activity.

(Negative isolation $243.7 \pm 52.6 \mathrm{U} / \mathrm{ml}$ ). The average activities and seasonal variations recorded by Lorenzen et al. (2010) of ALP was $774 \pm 260$ with min-max 328-1155U/1 in cow raw milk, Wernery et al. (2008) found a comparable ALP activity in cow's milk. Studies analysing raw milk from one cow breed showed average ALP activities of $330 \mathrm{U} / 1$ (Assis et al., 2000; Barbosa, 2005).

Analysis performed in Greece using bovine, ovine and caprine raw milk samples showed average ALP activities of 390, 2430 and $134 \mathrm{U} / 1$ (Vamvakaki et al., 2006). Milk from Alpine goats showed $128 \mathrm{U} / 1$ ALP in early lactation and $236 \mathrm{U} / 1$ in late lactation (Ying et al., 2002). Many results have revealed differences in ALP activities of raw milk that are dependent on breed, lactation stage and health state.

A lot of ALP originating from the mammary glands is found in the whey (Angelino et al., 1999 and Claeys et al., 2002) However, the influence of lactation on serum ALP activity has remained unknown. More complex researches of the structure and origin have shown that milk contains two forms of enzymes, one from myoepithelial cells and the other from cytoplasm (Bingham et al., 1992 and Bingham and Malin 1992).

(Tables 4,5) showed highly significant mean value of GGT in milk than in blood serum $(3152 \pm 322.1$ 
$\mathrm{U} / \mathrm{L}, 2565 \pm 414.3 \mathrm{U} / \mathrm{L})$ in two stage of lactation $(p<0.0001)$, these is may due to GGT is involved in the transportation of the amino acids from blood to mammary glands, playing an important role for biosynthesis of milk proteins. Similar result by liu et al. (2012) observed enzyme activities of GGT in milk was significantly higher than that in blood plasma. Add that, the activity of GGT in milk was almost thirty fold as much as that in blood plasma $(p<0.001)$. mean value $921.63 \pm 20.98 \mathrm{u} / \mathrm{l}$ in milk with contrast to blood plasma $17 \pm 0.32$. the same pattern in our study which is increase GGT activity in blood of two stage follow up by increase in milk in the consideration stage. Nearly averaged GGT values determined in the study of Lorenzen et al. (2010) was $4143 \pm 449 \mathrm{u} / 1$ with Min-max 3420-5190 U/1. McKellar et al. (1991) and Wernery et al. (2008) obtained comparable values of 4300 U/1 for cow's whole milk by applying the same method of analysis. Anjos et al. (1998) found on average 2880 U/1 GGT activity in raw cow's milk.

The corresponding average enzymatic values obtained in skimmed milk was $5503 \pm 654 \mathrm{U} / \mathrm{L}$ (Dumitraşcu et al., 2013). Elsewhere, we reported mean values for GGT activities of 4010and 3200 $\mathrm{U} / \mathrm{L}$ in whole and skimmed cow milk respectively by (Stănciuc et al., 2011). The results of this study are in fair agreement with those obtained by Zehetner et al. (1995) who measured a GGT activity of 5920 $\mathrm{U} / \mathrm{L}$ for raw cow milk. The authors add that differences in GGT activity in whole and skimmed milk are dependent on breed or health state of the animal (Fox, 2003).

Enzymes may be present during various milk stage depending on their primary localization, physicalchemical properties and the major reason of their existence in milk. The presence of enzymes in milk may be consequence of spontaneous diffusion of low molecular weight enzymes from plasma, active secretion from apical parts of the mammary gland epithelium or a result of enzymes leaving somatic cells which are present in secreted milk, most often leukocytes or other macrophage cells. However, the results of some studies showed that the activity of certain enzymes is much greater in milk and cannot be correlated to an increased activity in plasma (Kocić et al., 2010). It could by concluded that During the early stage of lactation the liver of productive cows undergoes extensive physiological and biochemical changes to counteract the adverse effects of negative energy balance. These metabolic disorders negatively affect chemical composition of blood and technological parameters of milk as enzyme. Comparing the values obtained in the study with other cattle showed higher blood levels of the enzymes indicating the more active metabolites and muscle mass resulting from a greater stress of lactation. And we could not find published reports that standardized AST,ALT,GGT, ALP and activities for normal bovine milk. Therefore, the measurement of enzyme activities appears to be a suitable diagnostic method for identifying infected mammary glands in early lactation or selective dry cow therapy, and requires further investigation.

\section{REFERENCES}

Abdel-Raheem, S.M.; Stur, S.I. and Iben, C. (2010): The use of blood profile, milk composition and body condation to evaluation the metabolic and nutrational status of Simmental dairy cows.14 Sci Cong., Fac. Vet. Med., Assiut Vet. Med. 449-467.

Ali, A.T.; Penny, C.B.; Paiker, J.E.; Chantal van Niekerk, Smit, A.; Ferris, W.F. and Crowther, N.J. (2005): Alkaline phosphatase is involved in the control of adipogenesis in the murine preadipocyte cell line, 3T3- L1. Clin Chim Acta, 354: 101-109.

Anderson, F.H.; Zeng, L.; Roch, N.R. and Yoshida, E.M. (2000): An assessment of clinical utility of serum ALT and AST in chronic hepatitis C. HEPATOL. Res., 18: 63-71.

Angelino, P.D.; Christen, GL.; Penfield, M.P. and Beattie, S. (1999): Residual alkaline phosphatase activity in pasteurized milk heated at various temperatures - measurement with the Fluorophos and Scharer rapid phosphatase tests. J. Food Protect 62, 81-85.

Anjos, F.D.; Machado, A.; Ferro, C.; Otto, F. and Bogin, E. (1998): Gamma glutamyl transferase as a marker for the pasteurisation of raw milk. J. Food Protect. 61, 1057-1059.

Assis, G.; De Bivar Roseiro, M.L. and Barbosa, M. (2000): Determination of alkaline phosphatase activity in milk from indigenous Portuguese ewe and goat breeds by the fluorometric method. FIL-IDF Bull. 351, 33.

Babaei, H.; Mansouri-Najand, L.; Molaei, M.M.; Kheradmand, A. and Sharifan, M. (2007): Assessment of lactate dehydrogenase, alkaline phosphatase and aspartate aminotransferase activities in cow's milk as an indicator of subclinical mastitis. Vet. Res. Comm., 31: 419-425.

Barbosa, M. (2005): Interest in Controlling Alkaline Phosphatase Activity in Sheep and Goat Milks. The Future of the Sheep, Goat Dairy Sectors. IDF-FIL, pp. 117-127 (Part 3, special issue 0501 .

Batavani, R.A.; Mortaz, E.; Falahian, K. and Dawoodi, M.A. (2003): Study on frequency, etiology and some enzymatic activities of subclinical ovine mastitis in Urmia, Iran. Small Ruminant Research, 50, 45-50.

Batavani, R.A.; Asri, S. and Naebzadeh, H. (2007): The effect of subclinical mastitis on milk 
composition in dairy cows. Iran. J. Vet. Res., 8: 205-211.

Bell, A.; Burhans, W.S. and Overton, T.R. (2000): Protein nutrition in late pregnancy, maternal protein reserves and lactation performance in dairy cows. Proceedings of the Nutrition Society. T. 59. P. 119-126.

Bingham, E.W.; Garver, K. and Powlem, D. (1992): Purification and properties of alkaline phosphatase in the lactating bovine mammary gland. J. Dairy Sci; 75: 3394-401.

Bingham, E.W. and Malin, E.L. (1992): Alkaline phosphatase in the lactating bovine mammary gland and the milk fat globule membrane. Release by phosphatidylinositolspecific phospholipase C. Comp Biochem Physiol, 102: 213-18.

Bjerre-Harpøth, V.; Friggens, N.C.; Thorup, V.M.; Larsen, T.; Damgaard, B.M.; Ingvartsen, K.L. and Moyes, K.M. (2012): Metabolic and production profiles of dairy cows in response to decreased nutrient density to increase physiological imbalance at different stages of lactation J. Dairy Sci. 95: 2362-2380.

Bobe, G.; Young, J.W. and Beitz, D.C. (2004): Invited review: Pathology, etiology, prevention, and treatment of fatty liver in dairy cows. Journal of Dairy Science 87, 3105-3124.

Bogin, E. and Ziv, G. (1973): Enzymes and minerals in normal and mastitic milk. Cornell Veterinarian, 63, 666-676.

Bogin, E.; Ziv, G.; Avidar, J.; Rivetz, B.; Gordin, S. and Saran, A. (1977): Distribution of lactate dehydrogenase isoenzymes in normal and inflamed bovine udders and milk. Research in Veterinary Science, 22, 198-200.

Brent, H. and Todd, D. (2003): Nutritional and metabolic profile testing of dairy cows. University of Guelph. AHL LabNote 4, 1-3.

Cardoso, F.; Tostes, S. and Lasta, C. (2008): Hematological, biochemical and ruminant parameters for diagnosis of left displacement of the abomasum in dairy cows from Southern Brazil. Pesq Agrop Bras Brasília 43: 141-147.

Carlson, G.P. (1996): Clinical chemistry tests. pp. 441-469. In: Large Animal Internal Medicine, 2nd ed. (Smith, B. P. ed.), Mosby-Year Book, St. Louis.

Calamari, L.; Maianti, M.G.; Bani, P. and Sarti, L. (2005): Seasonal variations of some enzyme activities of cow milk Ital. J. Anim. Sci. VOL. 4 (SUPPL. 2), 212-214.

Cincović, R.M.; Belić, B.; Radojičić, B.; Hristov, S. and Đoković, R. (2012): Influence of lipolysis and ketogenesis to metabolic and hematological parameters in dairy cows during periparturient period. Acta veterinaria (Beograd) 62, 4, 429-444.

Claeys, W.L.; Van Loey, A.M. and Hendrickx, M.E. (2002): Kinetics of alkaline phosphatase and lactoperoxidase inactivation, and of betalactoglobulin denaturation in milk with different fat content. J. Dairy Res. 69(4): 541553.

Deianov, M. (1983): LDH activity and isoenzyme spectrum in the leukocytes of cows with catarrhal mastitis and chronic endometritis. Vetrinarno Meditsinski Nauki, 20, 47-51.

Djoković, R.; Kurćubić, V.; Ilić, Z.; Cincović, M.; Fratrić, N.; Stanimirović, Z. and Petrović, $M$. (2013): Evaluation of the metabolic status of Simmental dairy cows in early and mid lactation. Animal Science Papers and Reports vol. 31 no. 2, 101-110 Institute of Genetics and Animal Breeding, Jastrzębiec, Poland.

Dumitraşcu, L.; Stănciuc, N. and Stanciu, S. (2013): The effect of heat treatment on $\gamma$-glutamyl transferase activity in non-bovine and bovine milk - A comparative kinetic and thermodynamic investigation. LWT - Food Science and Technology 51: 325-330.

El-sherif, M.M.A. and Assad, F. (2001): Changes in some blood constituents of barki ewes during pregnancy and lactation under semi arid condition. Small ruminant research, 40: 269277.

Filipejová, T. and Kováčik, J. (2009): Evaluation of selected biochemical parameters in blood plasma, urine and milk of dairy cows during the lactation period. Slovak J. Anim. Sci., 42, SUPPLEMENT 1: 8-12.

Fox, P.F. (2003): Significance of indigenous enzymes in milk and dairy products. In J. R. Whitaker, A.G.J. Voragen, \& D.W.S. Wong (Eds.), Handbook of food enzymology. New York: Marcel Dekker, Inc.

Fox, P.F. and Kelly, A.L. (2006): Indigenous enzymes in milk: Overview and historical aspects-Part 2, Inter. Dairy J., 16: 517-532.

Hanley, A.J.G.; Williams, K.; Festa, A.; Wagenknecht, L.E.; RB D'Agostino, Jr. and SM. Haffner (2005): Liver markers and development of the metabolic syndrome: the insulin resistance atherosclerosis study. Diabetes, 54: 3140-3147.

Heck, J.M.L.; Van Valenberg, H.J.F.; Djikstra, J.; Van Hooijodonk A.C.M. (2009): Seasonal variation in the Dutch bovine raw milk composition. Journal of Dairy Science,. T. 92. P. 4745-4755.

Herdt, T.H. (2000): Variability characteristics and test selection in herd-level nutritional and metabolic profiles testing. Veterinary Clinical North American Food animal Practice, 16, 387-403.

Heyneman, R. and Burvenich, C. (1992): Kinetics and characteristics of bovine neutrophil alkaline phosphatase during acute Eschericia coli mastitis. J. Dairy Sci., 75: 1826-1834. 
Joźwik, A.; Strzałkowska, N.; Bagnicka, E.; Grzybek, W.; Krzyżewski, J.; Poławska, E.; Kołataj, A. and Horbańczuk, J.O. (2012): Relationship between milk yield, stage of lactation, and some blood serum metabolic parameters of dairy cows. Czech J. Anim. Sci., 57, (8): 353-360.

Kaneko, J.J.; Harvey, J.W. and Bruss, M.L. (1989): In Clinical Biochemistry of Domestic Animals 5th ed. (Kaneko, J. J. ed.), Academic Press, Inc., San Diego. pp. 890-894.

Kaneko, J.J.; Harvey, W. and Bruss, M.L. (1997): Clinical Biochemistry of Domestic Animals. 5th edition Academic Press, San Diego, London, Boston, New York, Sydney, Tokyo, Toronto. Apendix VIII: Blood analyse reference values in large animals. pp. 890-894.

Kaneko, J.J.; Harvey, J.W. and Bruss, M.L. (2008): Clinical biochemistry of domestic animals, 6th Ed. Elsevier Academic, Amsterdam, pp: 356-365.

Kato, K.; Mori, K. and Katon, N. (1989): Contribution of leukocyte origin of lactate dehydrogenase isozymes in milk of bovine mastitis. Nippon Juigaku Zasshi. The Japanese Journal of Veterinary Science, 51, 530-539.

Katsoulos, P.D.; Christodoulopoulos, G.; Minas, A.; Karatzia, M.A.; Pourliotis, K. and Kritas, S.K. (2010): The role of lactate dehydrogenase, alkaline phosphatase and aspartate aminotransferase in the diagnosis of subclinical intramammary infections in dairy sheep and goats. J. Dairy Res. 77: 107-111.

Kaplwitz, N. (2000): Mechanism of liver injury. J. Hepatol., 32: 39-47.

Kauppinen, K. (1984): ALAT, AP, ASAT, GGT, OCT, activities and urea and total bilirubin concentrations in plasma of normal and ketotic dairy cows. Zbl. Vet. Med. A, 31, 567-576.

Kitchen, B.J. (1981): Review of the progress of dairy science: bovine mastitis: milk compositional changes and related diagnostic tests. Journal of Dairy Research, 48, 167-188.

Kocić, G.; Bjelaković, L.; Cvetković, T.; PopTrajković, Z.; Jonović, M.; Bjelaković, B.; Sokolović, D.; Jevtović, T. and Stojanović, D. (2010): Enzyme activity of human milk during the first month of lactation Acta Medica Medianae, Vol.49 (2).

Kramer, J.W. and Hoffman, W.E. (1997): Clinical Enzymology. In: Clinical Biochemistry of Domestic Animals. (Kaneko JJ, JW Harvey, ML Bruss, eds). Academic Press, San Diego, USA, pp: 303-325.

Lai, M.; Hyatt, B.J.; Nasser, I., Cyrry, M. and Fdhal, N.H.A. (2007): The clinical significant of persistently normal ALT in chronic hepatists B infection. J. Hepatol., 47: 760-767.

Liu, P.; He, BX.; Yang, XL.; Hou, XL.; Han, JB.; Han, YH.; Nie, P.; Deng, HF. and Du, XH.
(2012): Bioactivity evaluation of certain hepatic enzymes in blood plasma and milk of Holstein cows. Pak. Vet. J., 32(4): 601-604.

Liu, P.; Lu Hou, X.; Nie, P.; Hua Han, Y.; Fei Huang, Y.; Xing Zoun, Z.; Fang Deng, H.; Song, P.; Li, M. and Xiang He, B. (2013): Dynamic Monitoring of ALT and Correlation Analysis in Blood Plasma and Milk of Holstein Cows. Agricultural Journal 8 (1): 51-55, ISSN: 1816-9155.

Lorenzen, P.Chr.; Martin, D.; Clawin-Rädecker, I.; Barth, K. and Knappstein, K. (2010): Activities of alkaline phosphatase, $\gamma$ glutamyltransferase and lactoperoxidase in cow, sheep and goat's milk in relation to heat treatment Small Ruminant Research 89(1): $18-23$.

Marczuk, J. and Filar, J. (2003): An assessment of liver impairment and its functional disorders in the course of an excessive fat mobilization in dairy cows. Med. Weter 2003, 59, 47- 50 (in Polish).

McKellar, R.C.; Emmons, D.B. and Farber, J. (1991): Gamma-glutamyl transpeptidase in milk and butter as indicator of heat treatment. Int. Dairy J. 1, 241-251.

Meyer, D.J. and Harvey, J.W. (1998): Veterinary laboratory medicine. Interpretation and diagnosis. 2nd ed. WB Saunders Company, USA.

Michel, G. (1979): Histochemical behavior of succinate dehydrogenase and lactate dehydrogenase as well as ribonucleic acid in the epithelium of lactic ducts and alveoli of cowudder. Archiv fur Experimentelle Veterinarmedizin, 33, 745-751.

Milinković-Tur, S.; Perić, V.; Stojević, Z.; ZdelarTuk, M. and Piršljin, J. (2005): Concentrations of total proteins and albumins, and AST, ALT and GGT activities in the blood plasma of mares during pregnancy and early lactation. Vet. Arhiv, 75: 195-202. Mudroň P, J Rehage, HP Sallmann, M Höltershinken and H Schol.

Mohri, M.; Sharifi, K. and Eidi, S. (2007): Hematology and serum biochemistry of Holstein dairy calves: age related changes and comparison with blood composition in adults. Research in Veterinary Science, T.83. P. 30-39.

Mordak, R. and Nicpoń, J. (2006): Haematological and metabolic parameters of blood in cows in perinatal period and an increasing lactation. Med. Weter 62, 1292-1294 [in Polish].

Mulligan, F.J.; Ogrady, L.O.; Rice, D.A. and Doherty, M.L. (2006): A herd health approach to dairy cow nutrition and production diseases of the transition cow. Animal Reproduction, 96, 331-353. 
Nowakowski, H. (2008): The results of chosen biochemical parameters $i$ the aspect of functional state of liver in the course of primary ketosis in cows. Med. Weter 64, 197201 [in Polish].

Piccione, G.; Messina, V.; Marafioti, Si.; Casella, S.; Giannetto, C. and Francesco, F. (2012): Changes of some haematochemical parameters in dairy cows during late gestation, post partum, lactation and dry periods. ISSN 13922130. veterinarija ir zootechnika (Vet Med Zoot). T. 58 (80). 59-64.

Puoti, C.; Bellis, L.B.; Martellino, F.; Guarisco, R.; Dell-Unto, O.; Durola, L. and Galossi, A. (2005): Chronic hepatitis C and normal ALT levels: Treat the disease not the test. J. Hepatol., 43: 534-535.

Pyorala, S. (2003): Review article: Indicators of inflammation in the diagnosis of mastitis. Vet. Res., 34: 565- 578.

Rajala-Schultz, PJ.; Grohn, YT. and McCulloch, CE. (1999): Effects of milk fever, ketosis, and lameness on milk yield in dairy cows. J. Dairy Sci. 82, 288-294.

Ray, K.W.; Flamm, SL.; Di Bisceglie, AM.; Bodenheimer, HC. and PPCAASLD (2008): Serum activity of alanine aminotransferase (ALT) as an indicator of health and disease. Hepatology, 47: 1363-1370.

Rukkwamsuk, T.; Geelen, M.J.H.; Kruip, T.A.M. and Wensing, T. (2000): Interrelation of fatty acid composition in adipose tissue, serum and liver of dairy cows during the development of fatty liver postpartum. J. Dairy Sci., 83: 52-59.

Śamanc, H.; Danijela, K.; Stojić, V.; Dragica, S.; Vujanac, I.; Prodanović, R. and Slavica, B.K. (2011): Application of the metabolic profile in the prediction and diagnosis of fatty liver in Holstein cows. Acta Vet- Beograd, 61: 543-553.

Sarma, P.V. and Ray, T.K. (1985): Effect of physiological status on some blood enzyme levels and its relation to milk production Ind. J. Dairy Sci. 38:237-239.

Sattler, T. and Fürll, M. (2004): Creatine kinase and aspartate aminotransferase in cows as indicators for endometritis. J. Vet. Med. A. Physiol Pathol, 51: 132-137.

Sato, J.; Kanata, M.; Yasuda, J.; Sato, R.; Okada, K.; Seimiya, Y. and Naito, Y. (2005): Changes of serum alkaline phosphatase activity in dry and lactational cows. J. Vet. Med. Sci, 67, 813-815.

Sato, J.; Okada, K.; Fukuda, S.; Sato, R.; Yasuda, J. and Naito, Y. (2002)a: Serum activities of tartrate-resistant acid phosphatase and bone specific alkaline phosphatase as indices of bone metabolism in the cow J. Vet. Med. Sci. 64: 653-655.

Sato, J.; Okada, K.; Sato, R.; Yasuda, J. and Naito, Y. (2002)b: Serum activities of tartrate-resistant acid phosphatase in cows from farms where milk fever was frequent and farms where it was rare"J. Jpn. Med. Assoc.. 55. 580-583.

Sevinc, M.; Basoglu, A. and Guzelberta, H. (2003): Lipid and lipoprotein levels in dairy cows with fatty liver. Turkish Journal of Veterinary and Animal Science 27, 295-299.

SPSS (2000): Sample Power Statistics, SPSS 11.5, Syntax Reference Guide for SPSS Base. SPSS Inc., 233 South Wacker Drive, Chicago.

Stänciuc, N.; Dumitras, cu, L.; Râpeanu, G.; and Stanciu, S. (2011): $\gamma$-Glutamyl transferase inactivation in milk and cream: a comparative kinetic study. Innovative Food Science and Emerging Technologies, 12, 56-60.

Stojević, Z.; Piršljin, J.; Milinković-Tur, S.; ZdelarTuk M.; and Ljubić, B.B. (2005): Activitie Activities of AST, ALT and GGT in clinically healthy dairy cows during lactation and in the dry period. Vet. Arhiv, 75: 67-73.

Tennant, B.C. (1997): Hepatic Function. In: Clinical Biochemistry of Domestic Animals. (Kaneko JJ, JW Harvey and ML Bruss, eds) 5th Ed, Academic Press, San Diego, USA, pp: 327-352.

Vamvakaki, A.N.; Zoidou, E.; Moatsou, G.; Bokari, M. and Anifantakis, E. (2006): Residual alkaline phosphatase activity after heat treatment of ovine and caprine milk. Small Rumin. Res. 65, 237-241.

Veenhuizen, J.J.; Drackley, J.K.; Richard, M.J.; Sanderson, T.P.; Miller, L.D. and Joung, J.W. (1991): Metabolic changes in blood and liver during development and early treatment of experimental fatty liver and ketosis in cows. Journal of Dairy Science 74, 4238-4253.

Webber, M.; Krishnan, A.; Thomas, N.G. and Cheung, B.M.Y. (2010): Association between serum alkaline phosphatase and c-reactive protein in the United States National Health and Nutrition Examination Survey 2005-2006. Clin Chem Lab Med, 48: 167-173.

Wernery, U.; Fischbach, St.; Johnson, B. and Jose, Sh. (2008): Evaluation of alkaline phosphatase, g-glutamyl transferase and lactoperoxidase activities for their suitability as markers of camel milk heat inactivation. Milchwissenschaft 63, 265-267.

West, H.J. (1990): Effect on liver function of acetonaemia and the fat cow syndrome in cattle. Research in Veterinary Science 48, 221-227.

Ying, C.; Wang, H.-T. and Hsu, J.-T. (2002): Relationship of somatic cell count, physical, chemical and enzymatic properties to the bacterial standard plate count in dairy goat milk. Livest. Prod. Sci. 74, 63-77.

Zehetner, G.; Bareuther, C.; Henle, T. and Klostermeyer, H. (1995): Inactivation kinetics of $\gamma$-glutamyl-transferase during the heating of 
milk. Zeitschrift fur Lebensmitteluntersuchung und Forschung, 201, 336-338.

Zeinhom, M.M.A.; Abed, A.H. and Hashem, K.S.

(2013): A contribution towards milk enzymes, somatic cell count and bacterial pathogens associated with subclinical mastitis cows milk. Assiut Vet. Med. J. Vol. 59 No. 138.

\section{استبيان مستوى بعض الإنزيمات فى مصل الام واللبن أثناء مرحلتين من إدرار اللبن الأبقار الحلابة بمدينة اسبوط \\ غادة عبل العظيم محمد \\ Email: $\underline{\text { dr kada2012@yahoo.com }}$}

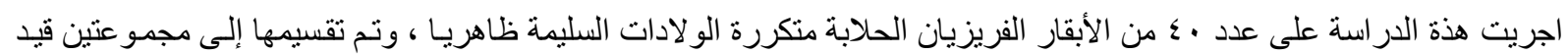

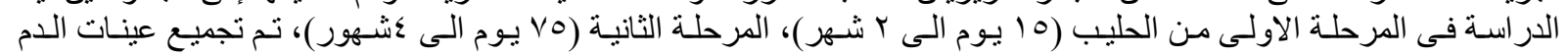

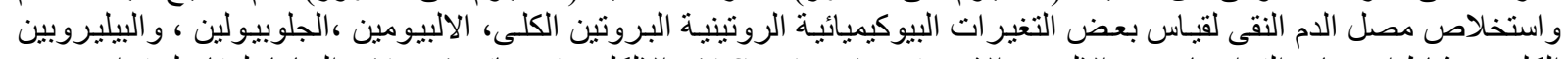

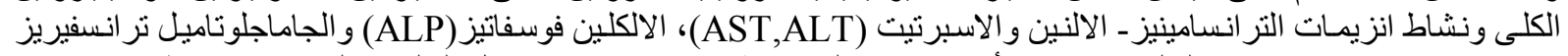
(GGT) (AST,ALT,ALP,GGT)

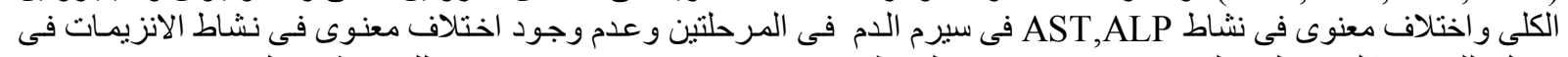

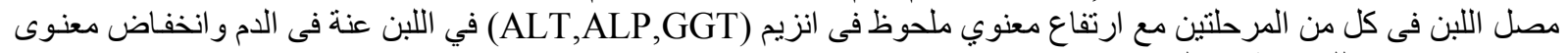
لانزيم AST فى اللبن عنة في اللى الدم. 